\title{
MONITORING AND MODELING OF HYDROLOGICAL PROCESSES IN THE SEMIARID REGION OF BRAZIL: THE CARIRI EXPERIMENTAL BASINS
}

\author{
Vajapeyam Srinivasan $^{1}$, Hugo Alcântara ${ }^{1}$, Carlos Galvão ${ }^{1}$, Ulisses Bezerra ${ }^{1}$, and John \\ Cunha $^{1}$ \\ ${ }^{1}$ Universidade Federal de Campina Grande
}

October 5, 2020

\begin{abstract}
Two experimental basins - the Cariri basins - were installed in a typically semiarid region in the State of Paraíba, Brazil, for obtaining reliable estimates of runoff and soil erosion in different scales to evaluate the influence of the human activities and other factors over the processes of runoff and erosion. In the first basin, located in the municipality of Sumé, the field studies were carried out at three different scales: four micro-basins with an area of around 0.5 ha; nine standard Wischmeier-type erosion plots of $100 \mathrm{~m} 2$ and seven sample plots of $1 \mathrm{~m} 2$. The experimental units had varied vegetal cover and management and, except the sample plots, were subjected to natural rainfall events only, and were monitored from 1982 to 1991 . The total runoff and total sediment yield were determined for each of the events of precipitation. The installations of the second basin, in the near municipality of São João do Cariri, were planned for the continuation of the studies initiated at Sumé, and include erosion plots (100 m2), micro-basins, and sub-basins, which are being monitored for runoff and sediment production up to now. Among them, two nested micro-basins were monitored to detect any scale effect at the micro-basin level. Nearly 600 events of natural precipitation, that produced runoff in at least one of the experimental units, have been registered. This bulk of data was utilised to evaluate the influence of various factors, including cultivation practices. The data collected so far has been successfully used to calibrate hydrological models for plots and micro-basins. Parameters have been tested by means of cross validations among micro-basins and sub-basins. The data sets, in part, have been made available to researchers in Brazil and now the updated data files are being made available to all the researchers in hydro-sedimentology at: https://doi.org/10.5281/zenodo.4044690
\end{abstract}

MONITORING AND MODELING OF HYDROLOGICAL PROCESSES IN THE SEMIARID REGION OF BRAZIL: THE CARIRI EXPERIMENTAL BASINS

Running Head : Brazilian Cariri Catchments

Vajapeyam S. Srinivasan ${ }^{1}$, Hugo M. de Alcântara ${ }^{2}$, Carlos de O. Galvão ${ }^{3}$, Ulisses A. Bezerra ${ }^{4}$, John E.de Brito Cunha ${ }^{5}$

Universidade Federal de Campina Grande, Campina Grande, PB, Brazil

1. Corresponding Author, vajapeyam@yahoo.com, mailing address: Rua Antonio Joaquim Pequeno 595, Campina Grande 58.429-105, PB, Brazil.

2. Hugo.morais@professor.ufcg.edu.br

3. Carlos.galvao@ufcg.edu.br

4. Ulisses.alencar17@gmail.com

5. John.e.cunha@gmail.com

\section{Acknowledgments}


SUDENE - the Superintendency for the Development of the Northeast of Brazil with the cooperation of ORSTOM - the French Government Agency for Technical Cooperation Overseas (now, Institut de Recherche pour le Développement- IRD), was responsible for implementing the program of Representative and Experimental Basins in the region beginning in the decade of 1970. Pierre Audry, Eric Cadier, Jean Leprun and Michel Molinier, hydrologists and soil scientists from France played key roles in the selection of site, installation of experimental units and beginning the operation of the EBS. Beronildo Freitas was the engineer from SUDENE responsible for technical coordination and administration. The contributions of other researchers and technical people have been listed by Srinivasan and Galvão (2003). The installation of the research catchment at São João de Cariri had the valuable collaboration of GTZ, the cooperation

Agency of the Government of Germany. Dr. Ing Ubald Koch was responsible for getting all the

equipment, installing them and conducting research work along with the members of the Hydrology Research Group of the Federal Universities of Paraiba and Campina Grande. Late prof. Manoel Gilberto de Barros efficiently coordinated the field work. Eduardo Figueiredo, Celso Santos and Ricardo Aragão have made note worthy contributions. The Ministry of Science and Technology of Brazil has provided the bulk of the financial support needed for the operation of the basins, through its main funding agencies of CNPq (National Council for Development of Science and Technology) and FINEP (Agency for Financing Research Studies and Projects).

\section{Hosted file}

HP2020 Key words_Abstract.pdf available at https://authorea.com/users/364110/articles/ 484642-monitoring-and-modeling-of-hydrological-processes-in-the-semiarid-region-ofbrazil-the-cariri-experimental-basins

\section{Hosted file}

HYP_Data Note_Main Text_Final.pdf available at https://authorea.com/users/364110/articles/ 484642-monitoring-and-modeling-of-hydrological-processes-in-the-semiarid-region-ofbrazil-the-cariri-experimental-basins

\section{Hosted file}

REFERENCES_DN.pdf available at https://authorea.com/users/364110/articles/484642-monitoringand-modeling-of-hydrological-processes-in-the-semiarid-region-of-brazil-the-caririexperimental-basins

\section{Hosted file}

HYP_Novelty and Int.pdf available at https://authorea.com/users/364110/articles/484642monitoring-and-modeling-of-hydrological-processes-in-the-semiarid-region-of-brazil-thecariri-experimental-basins

\section{Hosted file}

Table 1_DN.pdf available at https://authorea.com/users/364110/articles/484642-monitoringand-modeling-of-hydrological-processes-in-the-semiarid-region-of-brazil-the-caririexperimental-basins

\section{Hosted file}

Corr Author and Figure legends_DN.pdf available at https://authorea.com/users/364110/ articles/484642-monitoring-and-modeling-of-hydrological-processes-in-the-semiaridregion-of-brazil-the-cariri-experimental-basins 


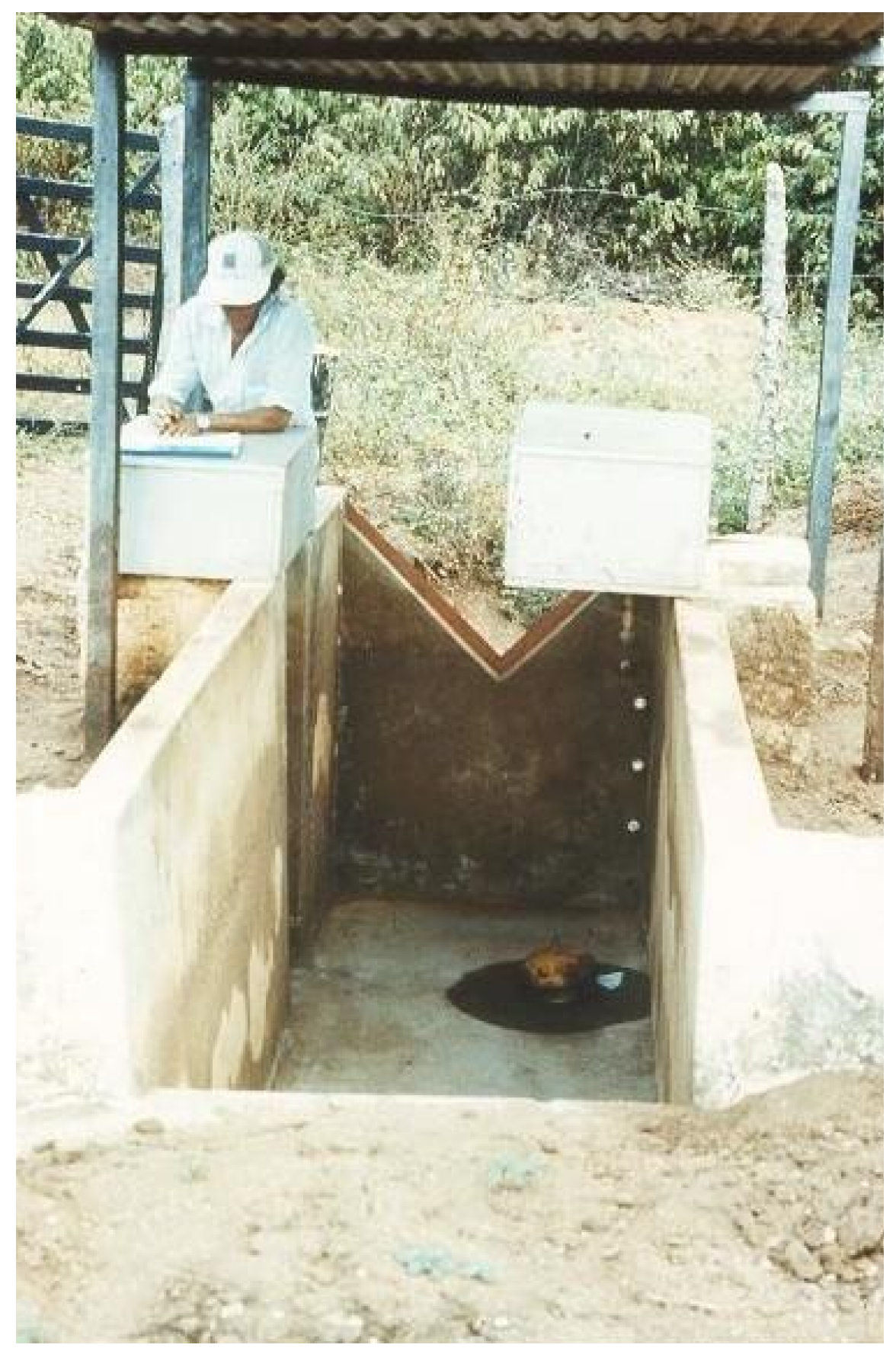



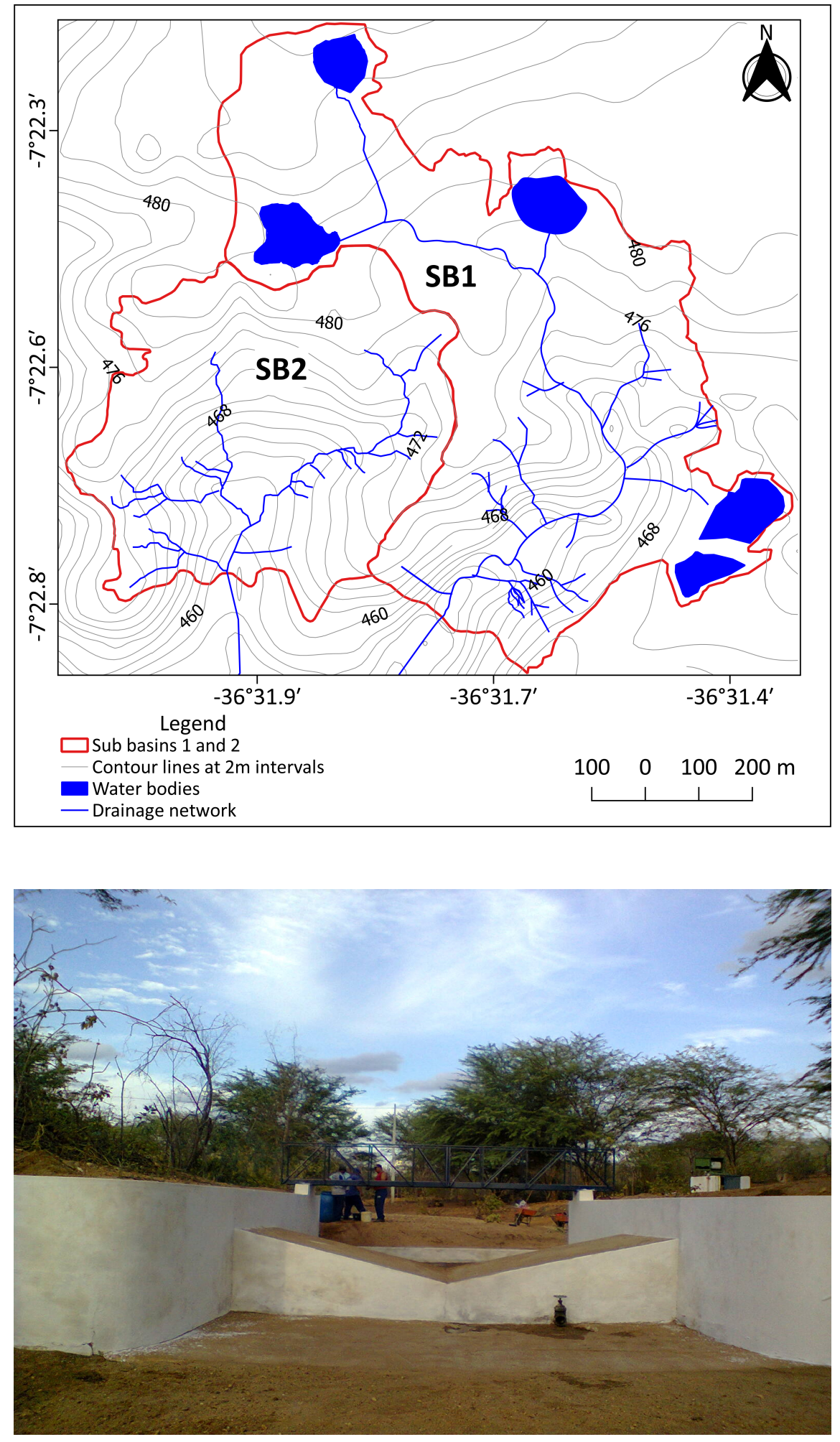


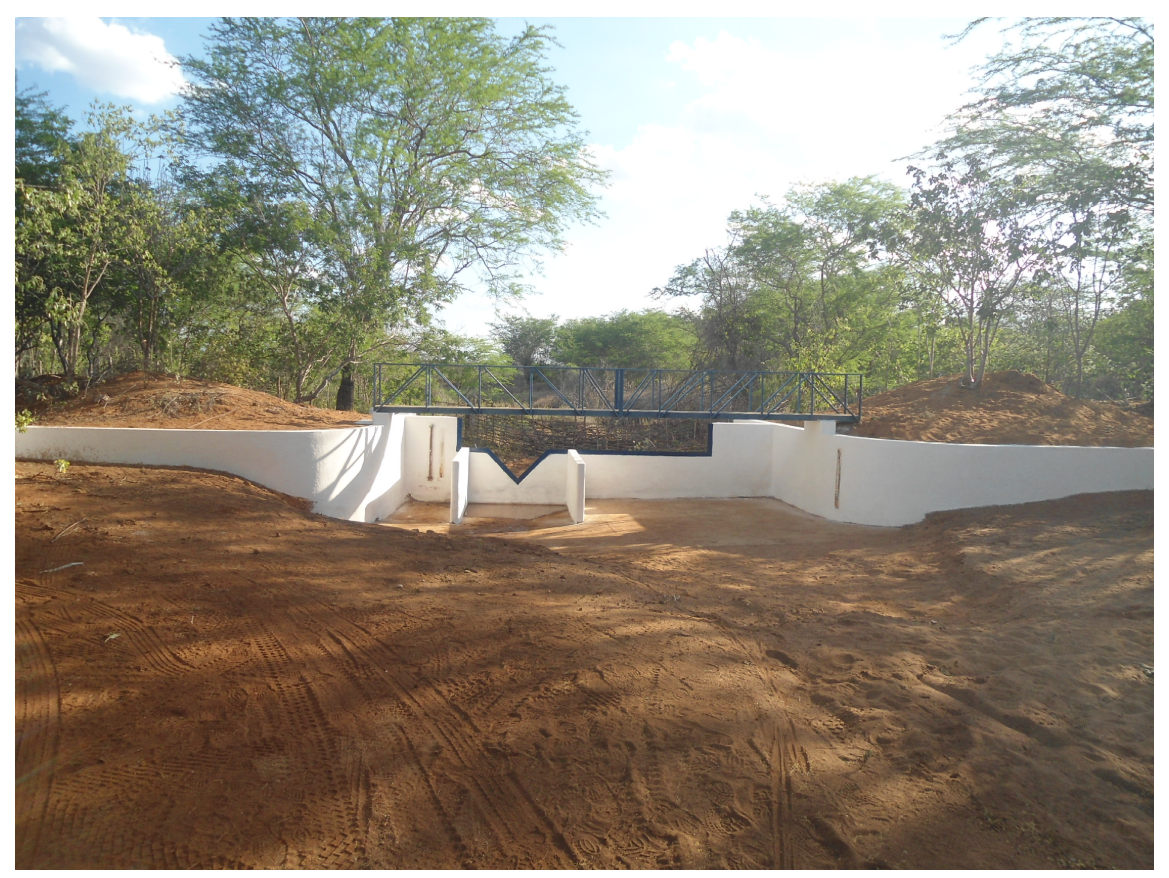

